\title{
Kainate Receptors Expressed by a Subpopulation of Developing Nociceptors Rapidly Switch from High to Low $\mathrm{Ca}^{2+}$ Permeability
}

\author{
C. Justin Lee, ${ }^{1}$ Haeyoung Kong, ${ }^{4}$ M. Chiara Manzini, ${ }^{2,3}$ Cristóvão Albuquerque, ${ }^{1}$ Moses V. Chao, ${ }^{4}$ and \\ Amy B. MacDermott ${ }^{1,3}$
}

${ }^{1}$ Department of Physiology and Cellular Biophysics, ${ }^{2}$ Department of Pathology, and the ${ }^{3}$ Center for Neurobiology and Behavior, Columbia University, New York, New York 10032, and ${ }^{4}$ Molecular Neurobiology Program, Skirball Institute, New York University Medical Center, New York, New York 10016

\begin{abstract}
Dorsal root ganglion (DRG) neurons first express kainate receptor subunits, predominantly GluR5, during embryonic development. In the DRG and throughout the nervous system, substantial editing of GluR5 mRNA occurs with developmental maturation (Bernard et al., 1999). The accompanying change in $\mathrm{Ca}^{2+}$ permeability of functional kainate receptors that is the predicted outcome of this developmental regulation of mRNA editing has not been investigated. Here we report that kainate receptors on DRG neurons from late embryonic and newborn rats are predominantly $\mathrm{Ca}^{2+}$ permeable but then become fully $\mathrm{Ca}^{2+}$ impermeable later in the first postnatal week. Using multiple markers for nociceptor subpopulations, we show that this switch in $\mathrm{Ca}^{2+}$ permeability is not caused by the appearance of a new subpopulation of nociceptors with different receptor properties. Instead, the change in $\mathrm{Ca}^{2+}$ permeability matches the time course of post-transcriptional RNA editing of
\end{abstract}

GluR5 at the Q/R site within the pore of the channel, indicating that the change is probably caused by developmentally regulated RNA editing. We also report that, on the basis of the strong correlation of receptor expression with expression of the surface markers LA4, isolectin B4, and LD2, kainate receptors are present on C-fiber-type neurons projecting to lamina II of spinal cord dorsal horn. These results raise the possibility that kainate receptors in their $\mathrm{Ca}^{2+}$-permeable form serve a developmental role in synapse formation between this population of C-fibers and their targets in the spinal cord dorsal horn. Thereafter, the receptors may serve a new function that does not require $\mathrm{Ca}^{2+}$ permeability.

Key words: dorsal root ganglion; nociceptor; kainate receptor; calcium permeability; capsaicin; LD2; LA4; IB4; lamina II; C-fiber
Kainate receptors, one of the three families of ionotropic glutamate receptors, are expressed by neurons in both the peripheral nervous system and the CNS. The receptors are composed of homomeric and heteromeric configurations of five cloned subunits: GluR5-7 and KA1 and KA2 (for review, see Chittajallu et al., 1999). Post-transcriptional mRNA editing of the GluR5 and GluR6 subunits results in replacement of a glutamine (Q) with an arginine $(\mathrm{R})$ at a site in the channel pore referred to as the $\mathrm{Q} / \mathrm{R}$ site (Sommer et al., 1991). This amino acid replacement strongly reduces $\mathrm{Ca}^{2+}$ permeability (Burnashev et al., 1995) and singlechannel conductance of the kainate receptor in heterologous expression systems (Swanson et al., 1996). Editing of GluR5 and GluR6 mRNA subunits begins during late embryonic development throughout the nervous system (Bernard and Khrestchatisky, 1994; Paschen et al., 1995; Bernard et al., 1999). The functional consequences of this change for some channel properties have been investigated (Ruano et al., 1995; Pemberton et al., 1998; Smith et al., 1999), although direct measurement of changes in the $\mathrm{Ca}^{2+}$ permeability of kainate receptors during development has not been made.

\footnotetext{
Received Dec. 22, 2000; revised April 11, 2001; accepted April 13, 2001.

This work was supported by the Christopher Reeve Paralysis Foundation and National Institutes of Health Grants NS 29797 and NS 40428. We thank Jane Dodd for the use of her microscope, David Julius for his generous gift of antibodies to VR1, and Aiming Shang and JiYong Kong for technical assistance.

Correspondence should be addressed to Dr. Changjoon Justin Lee, Department of Physiology and Cellular Biophysics, Columbia University, 630 West 168th Street BB1106, New York, NY 10032. E-mail: cj12@columbia.edu.

Copyright (C) 2001 Society for Neuroscience $0270-6474 / 01 / 214572-10 \$ 15.00 / 0$
}

GluR5 is expressed by a subset of mouse dorsal root ganglion (DRG) neurons early in embryonic development [embryonic day 12 (E12)] (Bettler et al., 1990), suggesting a developmental role for kainate receptors. Bernard et al. (1999) reported that in rat DRGs, the GluR5 receptor subunits change from being mostly unedited at E17 to being partially edited in the adult. These data suggest that there is a dynamic regulation of GluR5 editing during the critical period of late embryonic and early postnatal ages when robust changes in synaptic connectivity are occurring. However, the precise time course of changes in GluR5 editing in DRG neurons remains undetermined. Furthermore, the impact of subunit editing on functional channel properties such as $\mathrm{Ca}^{2+}$ permeability must be measured directly because receptor subunit composition as well as subunit editing will determine the relative number of $\mathrm{Ca}^{2+}$-permeable kainate receptors. Therefore, we have directly measured the degree of editing of GluR5 mRNA and the relative $\mathrm{Ca}^{2+}$ permeability of kainate receptors expressed by rat DRG neurons at different ages during early development.

One complication with studies of DRG neuronal properties is the heterogeneity of the neurons in the ganglia. Within DRG neuronal subpopulations, kainate receptors are expressed primarily by small-diameter neurons, presumably nociceptors (Huettner, 1990). However, it is clear that by any measure there are multiple subpopulations of nociceptors within the DRG. We have used the carbohydrate surface markers developed by Dodd and Jessell (1985), expression of the peptide substance P, and expression of the noxious heat- and capsaicin-sensitive vanilloid receptor VR1 
(Caterina et al., 1997, 2000) to define subpopulations of nociceptors. We have investigated the expression of kainate receptors by subpopulations of DRG neurons and the developmental changes in $\mathrm{Ca}^{2+}$ permeability that kainate receptors undergo.

\section{MATERIALS AND METHODS}

\section{Acute DRG preparation}

Postnatal day $0(\mathrm{P} 0)$ to $\mathrm{P} 8$ rats were deeply anesthetized with isoflurane and decapitated, and then cervical, thoracic, and lumbar DRGs were dissected out. To obtain E18 DRG neurons, a pregnant rat was anesthetized with $\mathrm{CO}_{2}$ and killed. Several embryos were removed and decapitated, and then cervical, thoracic, and lumbar DRGs were dissected out. Isolated DRGs were exposed for $10-20 \mathrm{~min}$ at $37^{\circ} \mathrm{C}$ to $1 \mathrm{mg} / \mathrm{ml}$ trypsin (type III; Sigma, St. Louis, MO) dissolved in the external bath solution without $\mathrm{CaCl}_{2}$ and $\mathrm{MgCl}_{2}$. Next, the trypsin was inactivated by addition of an equal volume of $1 \mathrm{mg} / \mathrm{ml}$ trypsin inhibitor (type II-O; Sigma) dissolved in the external bath solution with $\mathrm{CaCl}_{2}$ and $\mathrm{MgCl}_{2}$. DRGs were mechanically dissociated with fire-polished glass pipettes. Cells were washed twice by centrifuging and replacing the supernatant with fresh external bath solution. Cells were then plated on poly-D-lysinecoated glass coverslips and placed in an incubator for 1-8 hr. DRG neurons could be easily identified on the basis of their round morphology and large somal size $(15-40 \mu \mathrm{m})$.

\section{Simultaneous electrophysiology and $\mathrm{Ca}^{2+}$ imaging}

Acutely dissociated DRG neurons were loaded with $5 \mu \mathrm{M}$ fura- 2 AM for 15-20 min at room temperature and washed. Background-subtracted intensity images at two excitation wavelengths (340 and $380 \mathrm{~nm}$ ) were acquired using an intensified CCD camera and Axon Imaging Workbench 2.1 (Axon Instruments, Foster City, CA). Detailed methods are given elsewhere (Kyrozis et al., 1995; Gu et al., 1996). Kainateresponsive DRG neurons were initially identified by screening for cells that showed $\mathrm{Ca}^{2+}$ responses to $5 \mathrm{sec}$ applications of kainate $(100 \mu \mathrm{M})$. Then a recording electrode was applied to the kainate-responsive neuron.

All electrophysiological recordings were made using gramicidin perforated-patch electrodes. The pipette solution contained $25 \mu \mathrm{g} / \mathrm{ml}$ gramicidin $\mathrm{D}, 75 \mathrm{mM} \mathrm{Cs}_{2} \mathrm{SO}_{4}, 10 \mathrm{mM} \mathrm{NaCl}, 0.1 \mathrm{mM} \mathrm{CaCl}_{2}$, and $10 \mathrm{~mm}$ HEPES; $\mathrm{pH}$ was adjusted to $\mathrm{pH} 7.1$ with $\mathrm{CsOH}$, and osmolarity was adjusted to $310 \mathrm{mOsm}$ with sucrose. Pipette resistances ranged from 3 to $5 \mathrm{M} \Omega$. It took 20-30 min to achieve acceptable perforation, with final series resistances ranging from 15 to $40 \mathrm{M} \Omega$. Under the perforated-patch configuration, the fura-2 does not leak out from the cell body, allowing us to perform simultaneous recordings of whole-cell currents and $\mathrm{Ca}^{2+}$ imaging. Drug solutions were applied to cells by local perfusion through a capillary tube $(1.1 \mathrm{~mm}$ inner diameter) positioned near the cell of interest. The solution flow was driven by gravity (flow rate, $\sim 1-5 \mathrm{ml} / \mathrm{min}$ ) and controlled by miniature solenoid valves (The Lee Company, Westbrook, CT). Membrane currents or voltages were recorded using an Axopatch 200B amplifier (Axon Instruments), filtered at $2 \mathrm{kHz}$, and digitized at $2-5 \mathrm{kHz}$ with pClamp 6 acquisition software (Axon Instruments). The external bath solution contained $145 \mathrm{~mm} \mathrm{NaCl}, 5 \mathrm{~mm} \mathrm{KCl}$, $2 \mathrm{mM} \mathrm{CaCl}_{2}, 10 \mathrm{~mm}$ HEPES, $2 \mathrm{~mm} \mathrm{MgCl}_{2}$, and $5.5 \mathrm{~mm}$ glucose at $\mathrm{pH} 7.3$ and $325 \mathrm{mOsm}$. For the recordings that required $0 \mathrm{mM} \mathrm{Na}^{+}$and $10 \mathrm{~mm}$ $\mathrm{Ca}^{2+}(0 \mathrm{Na} / 10 \mathrm{Ca}), 145 \mathrm{~mm} \mathrm{NaCl}$ was replaced by $155 \mathrm{~mm} N$-methyl-Dglutamate and $144 \mathrm{~mm} \mathrm{HCl}$, in addition to $10 \mathrm{~mm} \mathrm{CaCl}_{2}$.

Agonist-evoked currents and $\mathrm{Ca}^{2+}$-imaging data were analyzed using the Mini Analysis Program (Synaptosoft, www.synaptosoft.com). Current amplitudes were calculated as the difference between the baseline and current amplitude at the end of drug application $(5 \mathrm{sec})$. The area under the curve was calculated by integrating a response trace from onset to offset of a drug application. The peak amplitude of the $\mathrm{Ca}^{2+}$ response was determined by subtracting the average baseline from the peak ratio value during a drug application. The relative $\mathrm{Ca}^{2+}$ permeability of the kainate receptors on each neuron was estimated by calculating the ratio of peak amplitude of the $\mathrm{Ca}^{2+}$ response over the corresponding area under the curve of the current response.

The current-voltage $(I-V)$ relationships for domoate-induced currents were obtained by performing $10 \mathrm{sec}$ voltage ramps $(-100$ to $+100 \mathrm{mV})$ before and during $10 \mu \mathrm{M}$ domoate application. The two traces were subtracted to obtain the $I-V$ relationship. The recordings were done in the presence of external bath solution containing $0.5 \mu \mathrm{M}$ tetrodotoxin (TTX) and $100 \mu \mathrm{M} \mathrm{CdCl}$. For some recordings, $10 \mathrm{~mm}$ lidocaine was used to block both voltage-gated sodium channels and $\mathrm{Ca}^{2+}$ channels
(Gu and MacDermott, 1997). The index of rectification for each $I-V$ relationship was calculated by taking the ratio of the slope conductance at +60 and $-60 \mathrm{mV}$ from each cell (Herb et al., 1992).

\section{GluR5 RNA-editing assay}

DRGs were isolated from embryos or postnatal rat pups at different ages (from E16 to P7). To get enough tissue, multiple embryos were dissected and included for each embryonic run per age. For postnatal and adult animals, the DRGs from only one animal were used for each run per age. At least three runs were used at each age, except for the adult that included only one run.

Reverse transcription-PCR. Total RNA was isolated from DRGs by Dounce homogenization in Trizol reagent (Life Technologies, Gaithersburg, MD) as instructed by the manufacturer. Five micrograms of total RNA were reverse transcribed in the presence of oligo-dT and reverse transcriptase. This cDNA template was used for PCR to amplify the region encoding TM2 of GluR5 by use of the upstream primer $5^{\prime}$ GTTTGTGATTGCGAGGTTCACA-3' and the downstream primer 5'CAGGTTGGCCGTGTAGGATGA-3'. Cycle conditions were as follows: 35 cycles of denaturation at $94^{\circ} \mathrm{C}$ for $1 \mathrm{~min}$, annealing at $60^{\circ} \mathrm{C}$ for $1 \mathrm{~min}$, and extension at $72^{\circ} \mathrm{C}$ for $1 \mathrm{~min}$.

RNA-editing analysis. The extent of $\mathrm{Q} / \mathrm{R}$ editing in TM2 of GluR5 was assessed by $B b v$ I digestion of the PCR products amplified from rat DRG. The restriction enzyme $B b v$ I recognizes the sequence GCAGC, which exactly corresponds to the sequence of unedited GluR5 mRNA. The amplified PCR product ( $233 \mathrm{bp}$ ) in the unedited state can be cleaved by $B b v \mathrm{I}$ to two fragments of 139 and $94 \mathrm{bp}$. These products were separated on $10 \%$ polyacrylamide-TBE gels and stained with ethidium bromide for visualization. Editing of GluR5 from GCAGC to GCGGC renders the latter DNA fragments refractory to $B b v \mathrm{I}$ digestion. Thus, the extent of RNA editing can be quantified by calculating the ratio of cleaved to uncleaved DNA.

\section{Immunocytochemistry of dissociated DRG neurons after $\mathrm{Ca}^{2+}$ imaging}

Dissociated DRG neurons were plated on coverslips with grids (Bellco Glass, Inc., Vineland, NJ) and loaded with fura-2 AM. Kainate (100 $\mu \mathrm{M})$ was applied to a field with cells for $5 \mathrm{sec}$. The criterion for the presence of kainate receptors was that the $\mathrm{Ca}^{2+}$ responses were five times the root mean square of the baseline $\mathrm{Ca}^{2+}$ signal. If there was a peak above this threshold at the time of drug application, the cell was considered positive for kainate receptor expression. Subsequently, bright-field images were taken of each field, and the location of the field was determined by the etched markings on the grid. After screening, the cells were prepared for immunostaining by being fixed with $4 \%$ paraformaldehyde in $0.1 \mathrm{M}$ phosphate buffer for $20 \mathrm{~min}$.

Coverslips were first incubated in a blocking solution of $10 \%$ normal goat serum in PBS with $0.1 \%$ Triton X-100 for 30 min. Primary antibodies were diluted in PBS with $0.1 \%$ Triton X-100 and $1 \%$ normal goat serum (PBS-TG). Polyclonal rabbit anti-VR1 (gift from Dr. David Julius) and anti-substance $\mathrm{P}$ (DiaSorin, Stillwater, MN) were used at 1:5000 dilution. SSEA4 (mouse IgG), LD2 (mouse IgM), and LA4 (mouse IgM) were purchased from Developmental Studies Hybridoma Bank (University of Iowa) and were used at dilutions of 1:1, 1:5, and 1:10, respectively. For the double immunostaining with isolectin B4 (IB4) and LA4, biotinylated-conjugated IB4 (Sigma) was used at 1:100 dilution, and Alexa488-streptavidin (Molecular Probes, Eugene, OR) was used as the secondary at 1:500 dilution. Secondary antibody indocarbocyanine (Cy3)-conjugated goat anti-rabbit IgG (Jackson ImmunoResearch, West Grove, PA) was used for anti-VR1 and anti-substance P at 1:500 dilution. Cy3-conjugated goat anti-mouse IgM (Molecular Probes) was used for LD2 and LA4, diluted 1:500. Cy3-conjugated goat anti-mouse IgG (Molecular Probes) was used for SSEA4 at 1:500 dilution. The secondary antibodies were applied in PBS-TG for $30 \mathrm{~min}$. Sections were mounted in ProLong Antifade (Molecular Probes). The cells were identified after immunostaining using the grids. We were able to relocate $>95 \%$ of the cells that we recorded with $\mathrm{Ca}^{2+}$ imaging.

The immunostaining was observed using a Zeiss Axioscope fluorescent microscope. Each staining was compared with a control that did not include primary antibody. Staining was considered positive if a cell displayed at least five times brighter intensity compared with that of the control staining. Most of the time, cells were examined by at least two independent observers to eliminate bias. 
A
P1

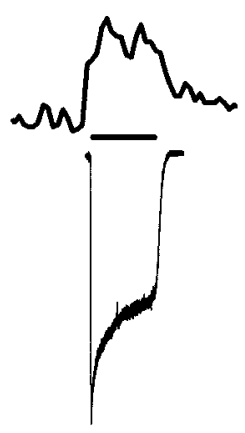

C

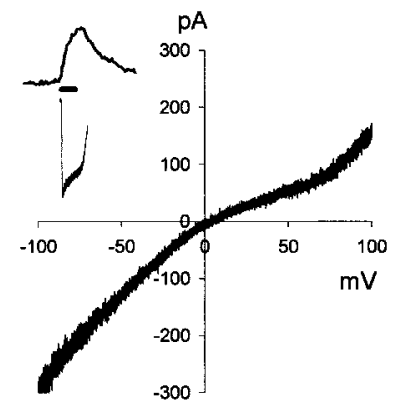

B

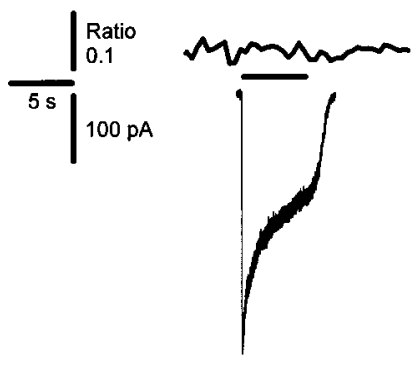

D $\quad$ P7

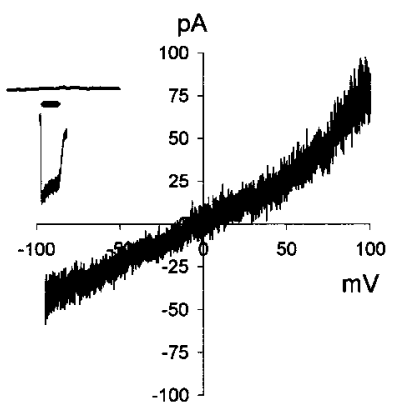

Figure 1. Postnatal DRG neurons express $\mathrm{Ca}^{2+}$-permeable and -impermeable kainate receptors. Acutely dissociated DRG neurons expressing kainate receptors were pre-identified by screening for a change in $\left[\mathrm{Ca}^{2+}\right]_{\mathrm{i}}$ in response to $100 \mu \mathrm{M}$ kainate. Neurons were then voltage clamped at $-70 \mathrm{mV}$ using the perforated-patched recording configuration. $A$, Kainate-induced inward current (bottom trace) is accompanied by a $\mathrm{Ca}^{2+}$ increase (top trace) in a $\mathrm{P} 1 \mathrm{DRG}$ neuron, indicating activation of $\mathrm{Ca}^{2+}$-permeable kainate receptors. $B$, Kainate-induced current in a $\mathrm{P} 4$ DRG neuron shows an amplitude similar to that of the neuron in $A$ but with no change in $\left[\mathrm{Ca}^{2+}\right]_{\mathrm{i}}$, indicating the predominant expression of $\mathrm{Ca}^{2+}$-impermeable kainate receptors. $C, I-V$ relationship of domoateinduced currents shows a doubly rectifying relation in a P1 DRG neuron different from that shown in $A$. A voltage ramp ( -100 to $100 \mathrm{mV}$ ) was introduced before and during the $10 \mu \mathrm{M}$ domoate application. The two resulting traces were subtracted to obtain the $I-V$ curve as shown. Inset, A high degree of $\mathrm{Ca}^{2+}$ permeability determined by simultaneous recording of $\left[\mathrm{Ca}^{2+}\right]_{\mathrm{i}}$ (top trace) and current (bottom trace) from this neuron $(n=5)$ is shown. The peak amplitudes of the $\mathrm{Ca}^{2+}$ response and domoateinduced current are 0.65 and $962 \mathrm{pA}$. D, A similar experiment in a P7 DRG neuron shows an outwardly rectifying $I-V$ relationship. Inset, The corresponding $\mathrm{Ca}^{2+}$ permeability is low $(n=3)$. The peak amplitude of the domoate-induced current is $297 \mathrm{pA}$. The horizontal bars above each current trace in $A-D$ indicate the duration of drug application.

\section{RESULTS}

\section{$\mathrm{Ca}^{2+}$ permeability of kainate receptors}

The $\mathrm{Ca}^{2+}$ permeability of kainate receptors expressed by DRG neurons was assessed using three different approaches. The first approach was to record simultaneously kainate-induced wholecell currents and $\mathrm{Ca}^{2+}$ transients from acutely dissociated postnatal DRG neurons. For this protocol, DRG neurons were screened for sensitivity to kainate using $\mathrm{Ca}^{2+}$ imaging. Then a perforated-patch recording electrode was sealed onto each responding neuron, and membrane currents were recorded under voltage clamp. Figure $1 A$ shows a recording from a P1 rat DRG neuron. In this example, kainate produced a strong inward current that was accompanied by an increase in intracellular $\mathrm{Ca}^{2+}$ concentration $\left(\left[\mathrm{Ca}^{2+}\right]_{\mathrm{i}}\right)$. In other cases, such as the example shown in Figure $1 B$ recorded from a P4 rat DRG neuron, the kainate-evoked inward current was not accompanied by an increase in $\left[\mathrm{Ca}^{2+}\right]_{\mathrm{i}}$. Because each neuron was voltage clamped and held at $-70 \mathrm{mV}$, there should be minimal contribution from voltage-gated $\mathrm{Ca}^{2+}$ channels to the kainate-evoked $\mathrm{Ca}^{2+}$ response.

The $I-V$ relationship for $\mathrm{Ca}^{2+}$-permeable kainate receptors has been shown to be inwardly rectifying, whereas for $\mathrm{Ca}^{2+}$. impermeable kainate receptors it is not (Burnashev et al., 1995). Therefore, the second approach we used to assess the presence of $\mathrm{Ca}^{2+}$-permeable kainate receptors was a voltage-ramp protocol. Domoate was used as the agonist in this series of experiments because it induces less desensitization of kainate receptors in DRG neurons than does kainate (Huettner, 1990).

Figure $1, C$ and $D$, shows the $I-V$ relationships for domoateevoked currents in DRG neurons from P1 and P7 rat pups, respectively (see Materials and Methods for $I-V$ curve generation from voltage ramps). $\mathrm{Ca}^{2+}$ permeability was initially tested by recording an $\left[\mathrm{Ca}^{2+}\right]_{\mathrm{i}}$ response to $10 \mu \mathrm{M}$ domoate with the membrane voltage clamped at $-70 \mathrm{mV}$ as shown in Figure 1, $C$ and $D$, insets. The ramp protocol was subsequently performed before, during, and after domoate application in the presence of $100 \mu \mathrm{M}$ $\mathrm{CdCl}_{2}$ to block voltage-gated $\mathrm{Ca}^{2+}$ channels and $0.5 \mu \mathrm{M}$ TTX to block TTX-sensitive voltage-gated $\mathrm{Na}^{+}$channel activation during the voltage ramp. In some cases the ramp protocol was performed in the presence of $10 \mathrm{~mm}$ lidocaine and $0.5 \mu \mathrm{M}$ TTX to suppress TTX-sensitive and -resistant sodium channels and voltage-gated $\mathrm{Ca}^{2+}$ channels (Gu and MacDermott, 1997). Figure $1 C$ shows an $I-V$ curve with inward rectification of the domoate-evoked current recorded from a neuron with $\mathrm{Ca}^{2+}$-permeable kainate receptors. In Figure $1 D$, the $I-V$ curve recorded from another neuron shows no inward rectification, consistent with the lack of $\left[\mathrm{Ca}^{2+}\right]_{\mathrm{i}}$ transient associated with the domoate-evoked current. These data demonstrate that the kainate receptors expressed by DRG neurons can be $\mathrm{Ca}^{2+}$ permeable or $\mathrm{Ca}^{2+}$ impermeable.

\section{Developmental changes in $\mathrm{Ca}^{2+}$ permeability of kainate receptors}

We tested whether the variable expression of $\mathrm{Ca}^{2+}$-permeable and -impermeable kainate receptors was caused by a developmentally regulated change in $\mathrm{Ca}^{2+}$ permeability of the kainate receptor. We recorded from $32 \mathrm{DRG}$ neurons prepared from rat pups at different ages during late embryonic development and the first postnatal week. To confirm that the kainate-induced responses were mediated by kainate receptors and not by AMPA receptors, 26 of 32 neurons were also tested for kainate sensitivity after preapplication of SYM 2081 (Fig. 2). This compound is a selective and strongly desensitizing agonist for kainate receptors (Zhou et al., 1997; Donevan et al., 1998) that we have used as a functional antagonist for kainate receptors on DRG neurons (Lee et al., 1999). In all cells tested in this study, the response to kainate was completely blocked by preapplication of SYM 2081. AMPA receptor-mediated responses to kainate were detected in DRG neurons in the presence of SYM 2081 (C. J. Lee, unpublished observation), but the frequency of occurrence was low (much $<1 \%$ of neurons tested). Twenty-one of 32 neurons were tested for capsaicin sensitivity (examples in Fig. 2); $71 \%$ were positive, indicating that they expressed functional VR1 protein, the receptor for capsaicin and noxious heat.

Kainate was applied in a $0 \mathrm{Na} / 10 \mathrm{Ca}$ bath to 5 of the 32 neurons as the third approach to assess $\mathrm{Ca}^{2+}$ permeability of kainate 
A

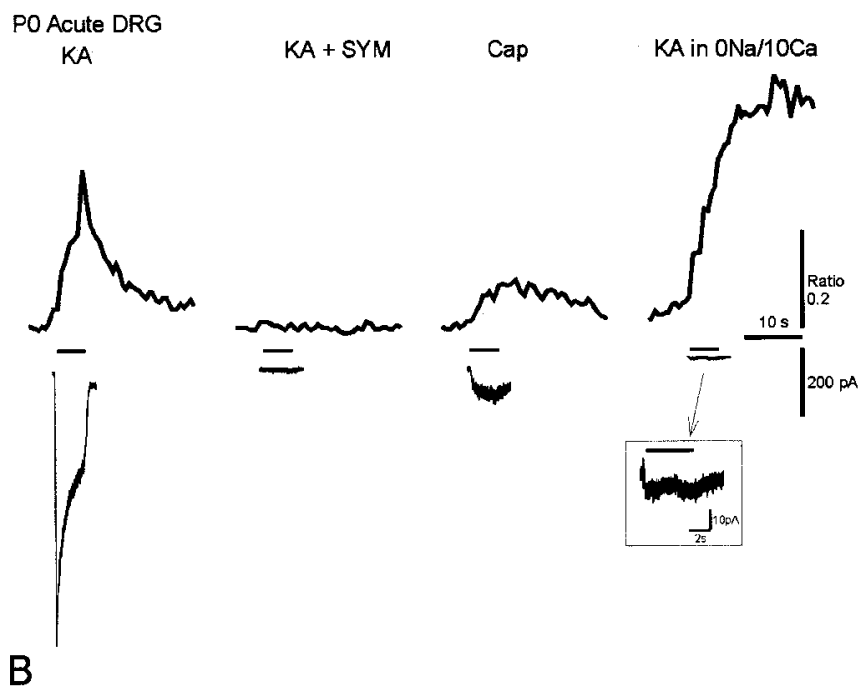

P3 Acute DRG

KA

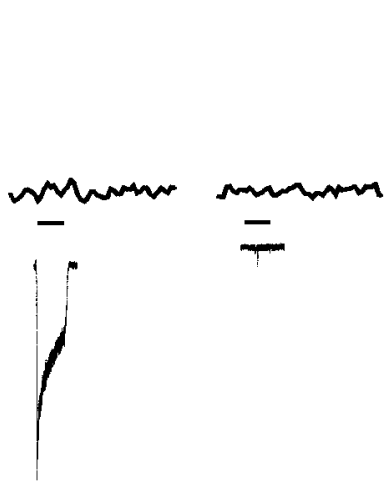

Cap

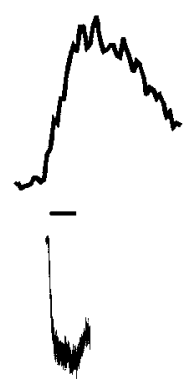

$\mathrm{KA}$ in $\mathrm{ONa} / 10 \mathrm{Ca}$

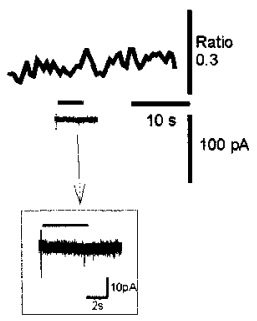

A

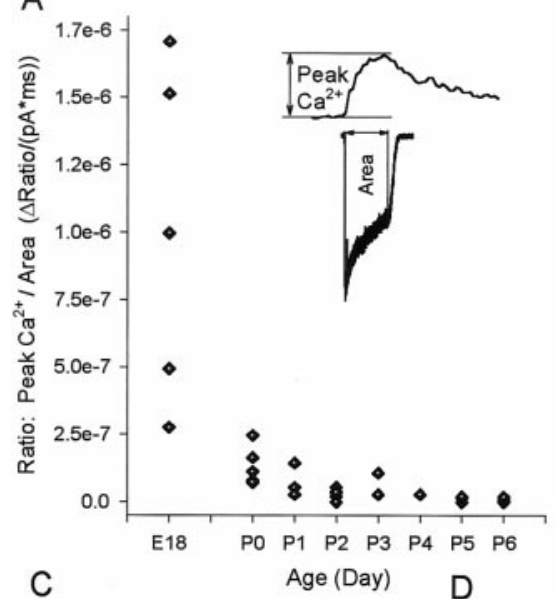

B

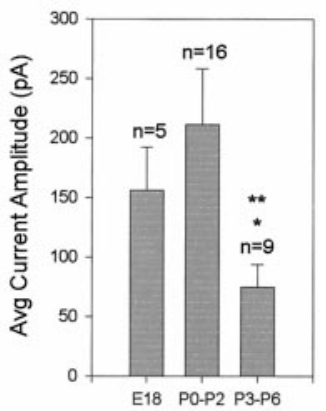

C
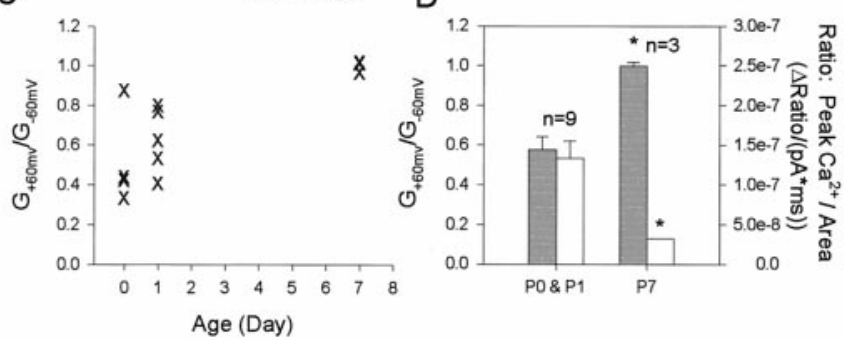

Figure 3. $\mathrm{Ca}^{2+}$ permeability of kainate receptors switches off during late embryonic and early postnatal development. $A$, The number of DRG neurons showing high $\mathrm{Ca}^{2+}$ permeability decreases with age. Each symbol represents a ratio of peak $\mathrm{Ca}^{2+}$ response normalized to the area under the curve of KA-induced current, as demonstrated in the inset. Each symbol represents one DRG neuron. Day 0 represents the day of birth (total $n=32)$. $B$, The E18 and neonate (P0-P2) animals show a larger current amplitude than do older animals. The average amplitudes of KA-induced currents are binned into three age groups: E18 $(n=5)$, $\mathrm{P} 0-\mathrm{P} 2(n=16)$, and P3-P6 $(n=9)$. Single and double asterisks indicate significant differences (based on Student's $t$ test) between P3-P6 and $\mathrm{P} 0-\mathrm{P} 2$ groups $(p<0.05)$ and between $\mathrm{P} 3-\mathrm{P} 6$ and E18 groups $(p<0.05)$, respectively. There was no significant difference between E18 and P0-P2 groups. $C$, The developmental change in $I-V$ relationship is shown. Each $X$ symbol represents the rectification index from one DRG neuron. The rectification index is expressed as the ratio of conductance at +60 and $-60 \mathrm{mV} . D$, The averages of the rectification indices at different ages are shown (gray bars, scale on left $y$-axis) along with the average $\mathrm{Ca}^{2+}$ permeabilities, calculated from the domoate-induced currents and $\mathrm{Ca}^{2+}$ responses (as in $A$; white bars, scale on right $y$-axis). The single asterisks indicate significant differences (based on Student's $t$ test) between P0-P1 and $\mathrm{P} 7$ groups $(p<0.05)$. The error bars indicate the SEM.

inward current in $0 \mathrm{Na} / 10 \mathrm{Ca}$ bath, indicating that essentially all of the kainate receptors were $\mathrm{Ca}^{2+}$ impermeable $(n=2$; Fig. $2 B)$.

The change in relative $\mathrm{Ca}^{2+}$ permeability of kainate-evoked currents as a function of postnatal age is shown in Figure $3 A$. The relative expression of $\mathrm{Ca}^{2+}$-permeable and -impermeable kainate receptors by individual DRG neurons was determined by simultaneous measurements of kainate-evoked changes in $\left[\mathrm{Ca}^{2+}\right]_{\mathrm{i}}$ and membrane current. $\mathrm{Ca}^{2+}$ permeability was expressed as the ratio of the peak $\mathrm{Ca}^{2+}$ response divided by the area under the curve of the corresponding current trace (see Fig. $3 A$, inset). High values of this ratio indicate a neuron expressing a higher proportion of kainate receptors that are $\mathrm{Ca}^{2+}$ permeable. As shown in Figure $3 A$, a greater proportion of neurons demonstrates high $\mathrm{Ca}^{2+}$ permeability at E18 and at approximately the time of birth. With increasing age, however, this permeability decreases. By $\mathrm{P} 4$ and older, most of the neurons displayed ratios close to zero, indicating that few or no $\mathrm{Ca}^{2+}$ - 
permeable kainate receptors contribute to the kainate-evoked currents from those cells. These results indicate that kainate receptors switch from $\mathrm{Ca}^{2+}$ permeable to $\mathrm{Ca}^{2+}$ impermeable at approximately the time of birth.

The overall kainate-evoked current amplitude decreased over the first postnatal week along with the $\mathrm{Ca}^{2+}$ permeability of kainate receptors, although not as dramatically. We grouped the current amplitude data into cells from three age groups: E18, $\mathrm{P} 0-\mathrm{P} 2$, and P3-P6. As shown in Figure 3B, neurons from E18 and P0-P2 pups showed significantly larger average current amplitudes than did neurons from P3-P6 pups. This demonstrates that age-dependent changes in $\mathrm{Ca}^{2+}$ permeability coincide with a decrease in current amplitude, raising the possibility that $\mathrm{Ca}^{2+}$ transients evoked by kainate are simply more difficult to detect from older neurons. However, as demonstrated in Figure 1, $A$ and $B$, there were many kainate-evoked currents with similar amplitudes yet with substantial differences in the size of the $\left[\mathrm{Ca}^{2+}\right]_{\mathrm{i}}$ transients.

If the $\mathrm{Ca}^{2+}$ permeability of kainate receptors is changing over the first postnatal week, the average shape of the $I-V$ relationship for domoate-evoked currents is also predicted to change over this time. The shapes of the $I-V$ relationships were compared by calculating a rectification index that should correlate with the relative number of $\mathrm{Ca}^{2+}$-permeable kainate receptors. We calculated the index of rectification for kainate-evoked currents from $\mathrm{P} 0-\mathrm{P} 1$ and $\mathrm{P} 7$ rats, and the results are shown in Figure 3, $C$ and $D$. The index of rectification used here is the ratio of slope conductances for domoate-evoked current at +60 and $-60 \mathrm{mV}$. A ratio of $<1$ indicates inward rectification. The index of rectification values plotted for cells from the $\mathrm{P} 0$ and $\mathrm{P} 1$ animals are all $<1$ (Fig. $3 C$ ). Average values are shown in Figure $3 D$ together with a representation of average relative $\mathrm{Ca}^{2+}$ permeability of kainate receptors on DRG neurons (as in Fig. $3 A$ ) from the same-age animals. Individual index of rectification values from P7 DRG neurons are significantly higher than those from P0 and P1 neurons (Fig. $3 C, D$ ), whereas the relative $\mathrm{Ca}^{2+}$ permeability at $\mathrm{P} 7$ is significantly lower (Fig. 3D).

\section{GluR5 mRNA-editing assay}

A loss of kainate receptor $\mathrm{Ca}^{2+}$ permeability in DRG neurons during late embryonic development into the first postnatal week is most simply explained by a change in editing of the GluR5 subunit. To test this hypothesis, we took whole DRGs from rats at different ages, reverse transcribed the mRNA, amplified a portion of the GluR5 subunit incorporating the Q/R site via PCR, and then used the restriction enzyme $B b v \mathrm{I}$ to cut this amplified product. Results of this editing assay are shown in Figure $4 A$. The 233 bp band represents the amplified PCR product of GluR5. BbvI was used to assess the extent of GluR5 editing because the unedited fragment can be digested by $B b v \mathrm{I}$ whereas the edited fragment cannot (Bernard and Khrestchatisky, 1994). The ratio of the density of the $233 \mathrm{bp}$ band in the presence of $B b v$ I over the density in the absence of $B b v \mathrm{I}$ was calculated. This ratio represents the extent of GluR5 editing at the mRNA level. The summary of multiple experiments is shown in Figure $4 B$. The percentage of editing at E16 is $22 \%$, and by the age of P7, most of GluR5 mRNA is edited (95\%). In another study, the extent of GluR5 Q/R editing in DRG was reported at only two time points as $11 \%$ at E17 and $56 \%$ at adult ages (Bernard et al., 1999). Apparent differences in these percentages compared with those we report here could be caused by differences in detection and quantification methods. Our data are consistent with the time
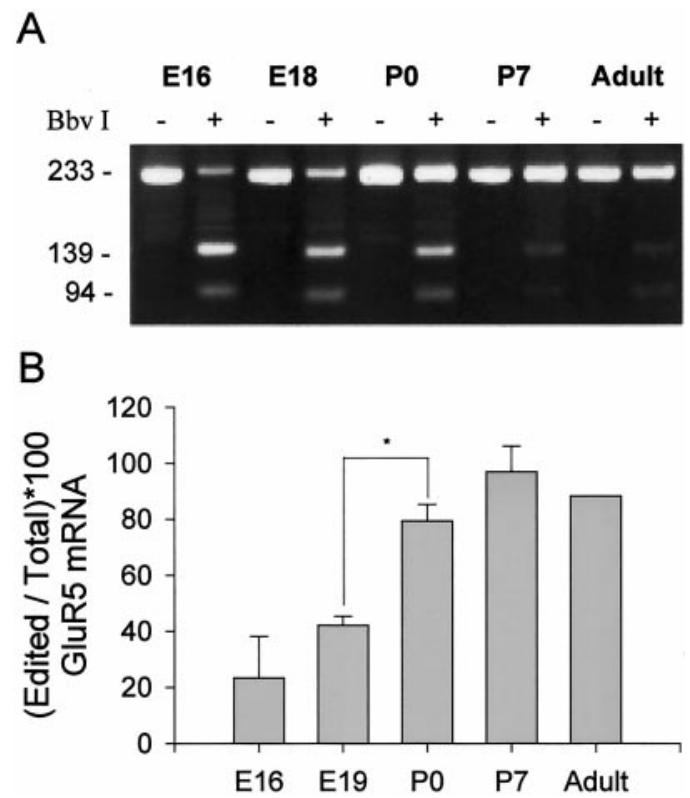

Figure 4. The extent of GluR5 editing sharply increases from embryonic day 16 through the first postnatal week, correlating well with the time course of the decrease in $\mathrm{Ca}^{2+}$ permeability. $A$, Unedited GluR5 decreases over the first postnatal week. After reverse transcription-PCR, isolated GluR5 transcripts were digested by the endonuclease $B b v \mathrm{I}$, separated on polyacrylamide-TBE gels, and stained with ethidium bromide for visualization. The presence of two bottom bands at 139 and 94 bp represents the unedited GluR5 digested by $B b v \mathrm{I}$. The remaining band on the top at 233 bp represents the amount of edited GluR5. B, The summary of the GluR5-editing assay. The extent of GluR5 editing at the Q/R site is measured by comparing the intensity of the top bands of the - column (no $B b v \mathrm{I}$ added) with that of the + column ( $B b v \mathrm{I}$ added). For each age point, at least three preparations of DRGs were used, except for the adult. The asterisk indicates a significant difference (based on Student's $t$ test) between E19 and P0 $(p<0.05)$. The error bars indicate the SEM. There is a progressive increase in the extent of editing until it is essentially complete at $\mathrm{P} 7$.

course of $\mathrm{Ca}^{2+}$ permeability shown physiologically in Figure 3 and support the hypothesis that the developmental increase in the extent of editing at the $\mathrm{Q} / \mathrm{R}$ site of GluR5 mRNA causes a decrease in the $\mathrm{Ca}^{2+}$ permeability and channel conductance of kainate receptors.

\section{Kainate receptors on identified subpopulations of nociceptors}

Another explanation for the change of $\mathrm{Ca}^{2+}$ permeability of kainate receptors could be the disappearance of a population of neurons that express kainate receptors with high $\mathrm{Ca}^{2+}$ permeability and the appearance of a new population of neurons expressing kainate receptors with low $\mathrm{Ca}^{2+}$ permeability. To test this possibility, we used several markers to define subpopulations of DRG neurons operationally and then determined which ones express kainate receptors. Labeling was performed using immunocytochemistry for known markers of nociceptors including antibodies to VR1, LA4, LD2, SSEA4, and substance P. VR1 is the protein receptor for noxious heat and is expressed by noxious heat-sensitive nociceptors (Caterina et al., 1997, 2000) projecting to lamina I, II, V, and X in the spinal cord (Tominaga et al., 1998). LA4 labels a subpopulation of DRG neurons that do not express substance $\mathrm{P}$, that display properties of $\mathrm{C}$-fiber-type nociceptors, and that project predominantly to inner lamina II of the superficial dorsal horn (Dodd and Jessell, 1985; Stucky and Lewin, 1999; 

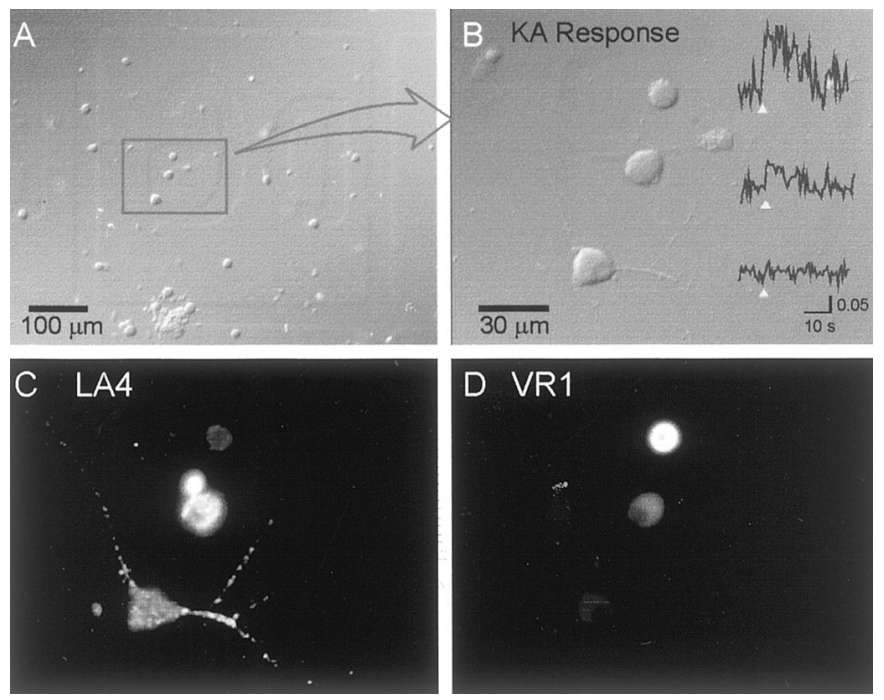

Figure 5. Subpopulations of nociceptors express kainate receptors. Acutely dissociated DRG neurons were plated on glass coverslips with grids. Each grid has unique lettering, which helped us to relocate the same field of view after $\mathrm{Ca}^{2+}$ imaging followed by immunostaining with various markers. $A, B$, The area in the rectangle in $A$ is zoomed in $B$. A field is imaged, and kainate is applied to look for kainate receptor-mediated responses. Traces in $B$ show that only the top two cells had $\mathrm{Ca}^{2+}$ responses to $100 \mu \mathrm{m}$ kainate. $C, D$, The same field of neurons in $B$ costained with LA4 and VR1 is shown. The top two cells show VR1 expression $(D)$, whereas the bottom two cells show LA4 expression $(C)$.

Fang et al., 2000). These neurons are also identified by the lectin IB4 (see below). LD2 and SSEA4 mark DRG neurons that project predominantly to outer lamina II and laminas I and III, respectively, and are substance $\mathrm{P}$ negative (Dodd and Jessell, 1985). Substance P-expressing DRG neurons are nociceptors that project to lamina I and outer lamina II (Todd and Spike, 1993). Marker information is summarized (see Fig. 6A).

Figure 5 shows a typical experiment including cells with and without kainate receptors that were labeled with LA4 and VR1. DRG neurons from P1 rat pups were acutely dissociated and plated on glass coverslips pre-etched with labeled grids (Fig. 5A; see Materials and Methods). Three neurons shown in the rectangle of Figure $5 A$ were tested for sensitivity to kainate. The top two DRG neurons had kainate-induced changes in $\left[\mathrm{Ca}^{2+}\right]_{i}$, whereas the bottom cell did not (Fig. 5B). After screening multiple fields of cells in this way for the presence of kainate receptors, neurons on each coverslip were fixed and labeled with one or two antibodies. The top cell in Figure $5 C$ was negative for LA4 but was strongly positive for VR1 (Fig. 5D). The middle cell showed strong staining for LA4 and intermediate staining for VR1. The bottom cell showed no staining for VR1 but was strongly positive for LA4.

In the absence of voltage-clamp control, kainate-induced changes in $\left[\mathrm{Ca}^{2+}\right]_{\mathrm{i}}$ are mediated by a direct $\mathrm{Ca}^{2+}$ influx through $\mathrm{Ca}^{2+}$-permeable kainate receptors, by indirect activation of voltage-gated $\mathrm{Ca}^{2+}$ channels, or by both. It follows that detection of DRG neurons expressing $\mathrm{Ca}^{2+}$-impermeable kainate receptors with kainate application requires the presence of voltagegated $\mathrm{Ca}^{2+}$ channels. Therefore, we tested whether all P1 DRG neurons express these channels. We found that $100 \%$ of P1 DRG neurons tested for sensitivity to depolarization by $90 \mathrm{~mm} \mathrm{KCl}$ solution $(n=120 / 120)$ displayed a robust increase in $\left[\mathrm{Ca}^{2+}\right]_{\mathrm{i}}$ that was readily blocked by $100 \mu \mathrm{M} \mathrm{CdCl} l_{2}$. Therefore our functional test for the presence of kainate receptors based on $\left[\mathrm{Ca}^{2+}\right]_{\mathrm{i}}$

\begin{tabular}{|c|c|c|c|c|c|}
\hline & VR1 & LA4 & LD2 & SSEA4 & Sub P \\
\hline $\begin{array}{c}\text { Primary laminar } \\
\text { termination site }\end{array}$ & $\mathrm{I}, \mathrm{II}, \mathrm{V}, \mathrm{X}$ & $\mathrm{I}_{\mathrm{i}}$ & $\mathrm{IL}_{\mathrm{o}}$ & $\mathrm{I}, \mathrm{III}$ & $\mathrm{I}, \mathrm{I}_{\mathrm{o}}$ \\
\hline Function/properties & $\begin{array}{c}\text { Heat, } \\
\text { capsaicin }\end{array}$ & $\begin{array}{c}\text { IB4, FRAP, } \\
\text { somatostatin }\end{array}$ & $\begin{array}{c}\text { Some FRAP, } \\
\text { somatostatin }\end{array}$ & $\begin{array}{c}\text { Globoseries } \\
\text { carbolydrate }\end{array}$ & peptide \\
\hline
\end{tabular}

B
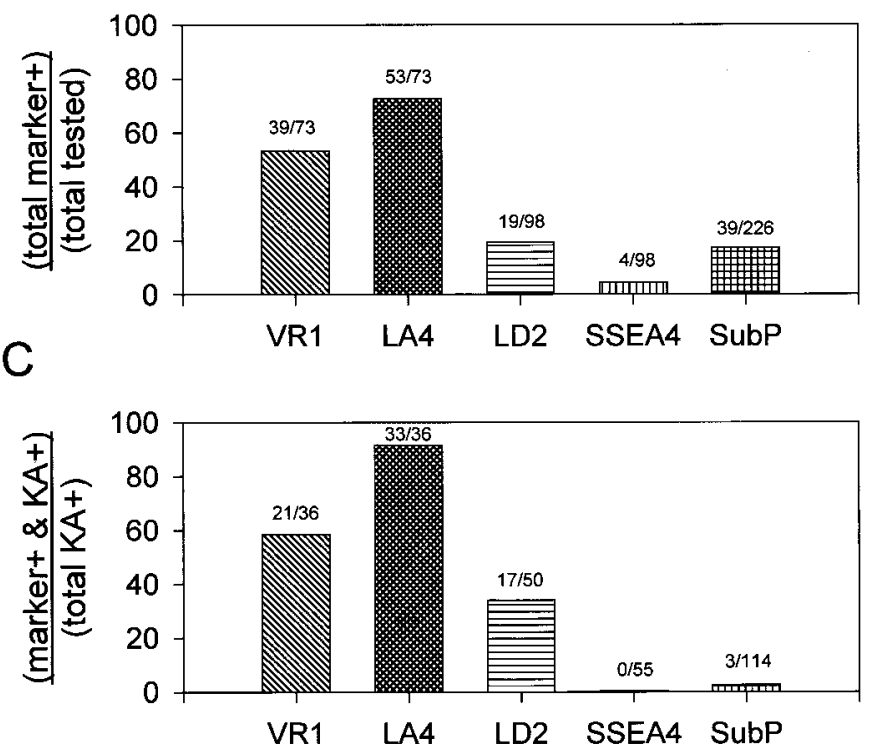

$\mathrm{D}$

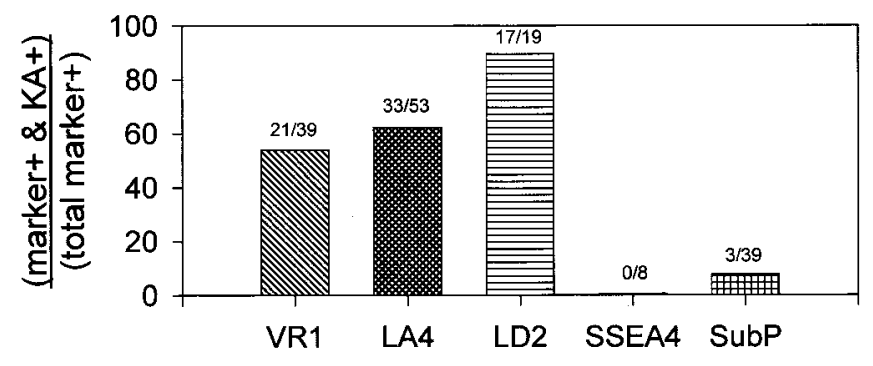

Figure 6. Many LA4- and LD2-positive DRG neurons express kainate receptors, but SSEA4- and substance P-positive DRG neurons do not. $A$, The table summarizes laminar projections and relevant functions or properties of the DRG neurons identified by the individual markers. References are given in Results. $B$, The percentage of total neurons expressing each marker is shown. Only cells tested with kainate application are included. $C$, The percentage of kainate-responsive neurons expressing each marker is shown. Over $90 \%$ of the total kainate-responsive neurons also expressed LA4. D, The percentage of neurons showing sensitivity to kainate within each labeled subpopulation is shown. Over $90 \%$ of the LD2-positive neurons have kainate responses. All data are from P1 acutely dissociated DRG neurons. Numbers above each bar indicate the number of cells over the total. FRAP, Fluoride-resistant acid phosphatase; SubP, substance P.

elevation was a good indicator of the presence of kainate receptors, regardless of the relative level of $\mathrm{Ca}^{2+}$-permeable receptors.

Using this approach, the percentage of neurons within each labeled DRG neuron population expressing kainate receptors and the distribution of differently labeled populations of DRG neurons within the population of kainate-sensitive neurons were determined, and the results are summarized in Figure 6. The distribution of each marker assayed within populations of acutely dissociated DRG neurons tested for sensitivity to kainate is shown in Figure 6B. Approximately half of all neurons tested 

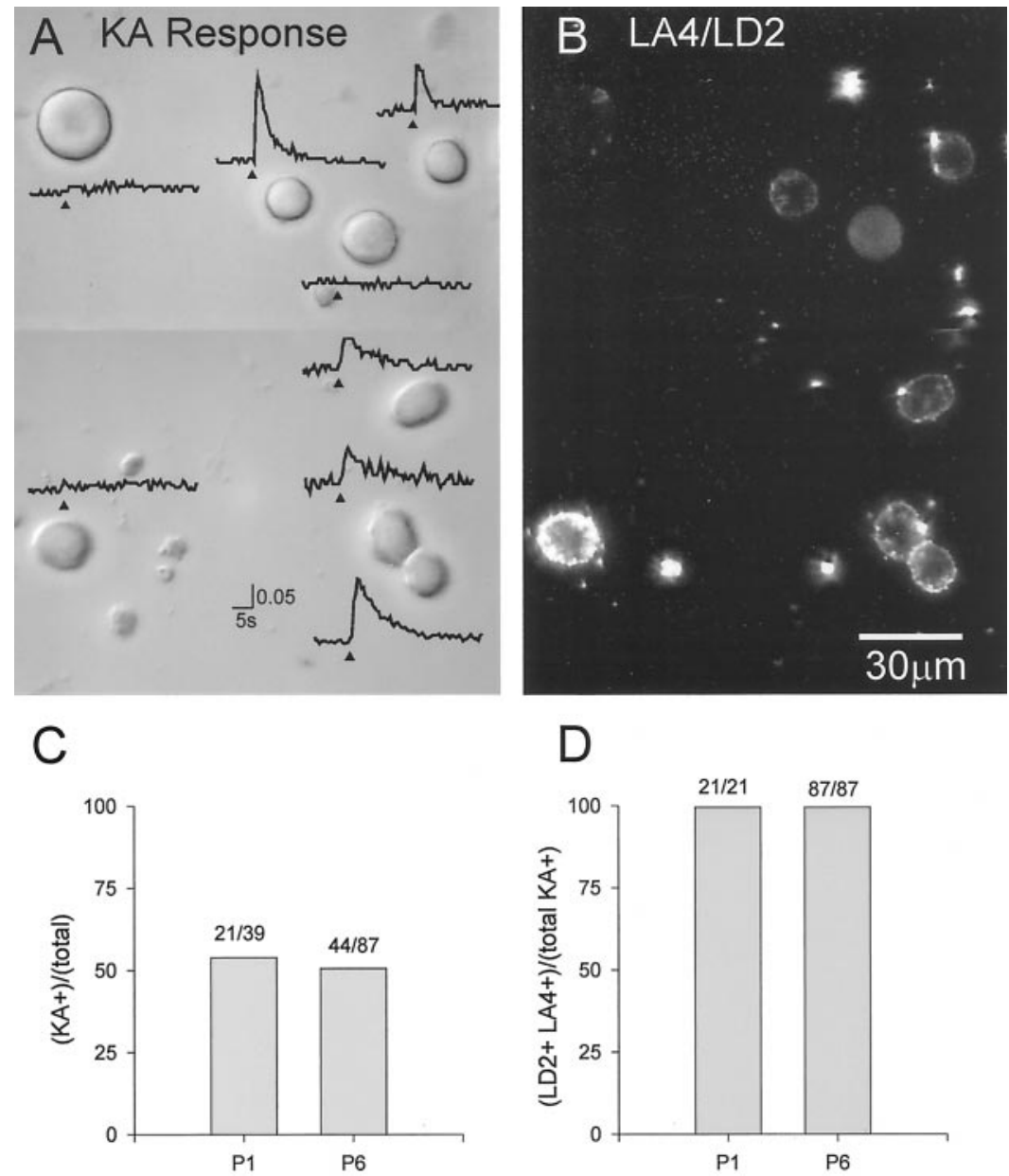

Figure 7. One hundred percent of the DRG neurons expressing kainate receptors are included in the LA4 and LD2-labeled subpopulation both at P1 and P6. A, Five of eight P6 DRG neurons show $\mathrm{Ca}^{2+}$ responses to kainate, whereas three do not. $B$, The cells were fixed and then stained with both LA4 and LD2. Seven of eight neurons show a positive staining with LA4 and LD2. One large DRG neuron on the top left shows negative staining with LA4 and LD2 and no $\mathrm{Ca}^{2+}$ response to kainate. $C$, The percentages of kainateresponsive neurons are similar in P1 and P6 DRG neurons. $D$, All of the kainate-responsive neurons show expression of LA4 and LD2 in P1 and P6. The numbers above each bar represent the number of positive neurons over the total.

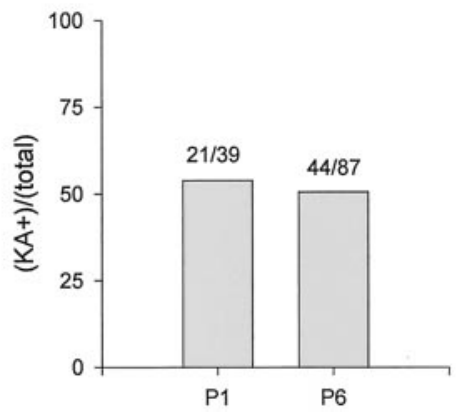

showed $\mathrm{Ca}^{2+}$ responses to $100 \mu \mathrm{M}$ kainate (200/397). Of the 73 cells assayed for kainate sensitivity and VR1 expression, approximately half were positive for VR1 $(53 \%)$. Seventy-two percent of the DRG neurons tested were LA4 positive, the single largest population, whereas LD2, substance $\mathrm{P}$, and SSEA4 each labeled $<20 \%$ of the neurons tested.

Of the DRG neurons that tested positive for kainate responses, $92 \%$ were positive for LA4 (Fig. 6 C). We have also tested the relationship between LA4 and IB4 labeling of DRG neurons. Ninety-eight percent of IB4-positive neurons $(n=573 / 584$; data not shown) double labeled with LA4, whereas $92 \%$ of LA4positive neurons labeled with IB4. Thus DRG neurons marked by LA4 are virtually identical to those marked by IB4. It follows that the vast majority of the neurons expressing kainate receptors in our acutely dissociated DRG neuron preparations were of the LA4 and IB4 cell types. This would suggest that few if any of the substance P- or SSEA4-positive DRG neurons should have responses to kainate, and this is evident in Figure $6 C$. Essentially none of the cells in these two populations expressed detectable kainate responses. Thirty-four percent of the kainate-responsive neurons were LD2 positive (Fig. 6C). Finally, $60 \%$ of kainateresponsive neurons were VR1 positive. These data indicate that kainate receptors are expressed by nociceptors, some of which are sensitive to noxious heat.

We then examined what proportion of each labeled subpopulation of DRG neurons expressed kainate receptors (Fig. 6D). Sixty-two percent of LA4-positive neurons are kainate responsive. Taken together with the data in Figure $6 C$, this means that although a kainate-responsive neuron is highly likely to be LA4 positive, an LA4-positive neuron is only modestly likely to be kainate responsive. This contrasts with LD2-positive neurons of which $90 \%$ are kainate responsive. These data indicate that LD2 is a useful marker for pre-identifying kainate receptor-expressing DRG neurons. We directly tested whether LA4 and LD2 together were able to identify all of the kainate-responsive neurons and found that indeed they marked $100 \%$ of the kainate-responsive neurons (see Fig. 7). SSEA4-positive neurons were rare in the acutely prepared DRG neuron populations under study (Fig. 6B). Therefore, for the data shown in Figure $6 D$, only four of eight neurons were prelabeled with SSEA4 and then tested for sensitivity to kainate. Figure $6 D$ shows that none of the eight SSEA4positive DRG neurons tested were sensitive to kainate. Finally, only $8 \%$ of the substance P-positive cells were sensitive to kainate.

Because LA4 and LD2 identify all of the DRG neurons that express kainate receptors, we used these two markers together to test whether there is a change in the population of DRG neurons expressing kainate receptor over the first postnatal week. Figure $7 A$ shows eight DRG neurons from a P6 rat pup, five of which have $\mathrm{Ca}^{2+}$ responses to $100 \mu \mathrm{M}$ kainate. Figure $7 B$ shows that seven of eight neurons have positive staining for LA4 and LD2. The one larger cell on the top left is negative for LA4 and LD2 and insensitive to kainate. We found that the percentage of kainate-responsive neurons did not change from $\sim 50 \%$ between P1 and P6 (Fig. 7C). Furthermore, we found that combined staining with LA4 and LD2 marked $100 \%$ of the nociceptors 
expressing kainate receptor at both $\mathrm{P} 1$ and P6 (Fig. 7D). These data indicate that changes in the $\mathrm{Ca}^{2+}$ permeability of kainate receptors occur in the subpopulation of nociceptors defined by LA4 and LD2.

\section{DISCUSSION}

We have directly tested $\mathrm{Ca}^{2+}$ permeability of kainate receptors expressed by sensory neurons in DRG. The receptors are mostly $\mathrm{Ca}^{2+}$ permeable before birth but switch to being $\mathrm{Ca}^{2+}$ impermeable early in the first postnatal week. The time course of this switch correlates with the developmental time course of GluR5 mRNA editing. Using a variety of markers for subpopulations of DRG neurons, we have shown that DRG neurons expressing kainate receptors both at birth and at the end of the first postnatal week are a subpopulation of C-fiber-type nociceptors that projects to lamina II of the spinal cord dorsal horn.

\section{$\mathrm{Ca}^{2+}$ permeability of kainate receptors in DRG neurons}

Using simultaneous recording of kainate-induced current and $\mathrm{Ca}^{2+}$ transients, we have demonstrated for the first time that kainate receptors expressed by embryonic and neonatal DRG neurons are $\mathrm{Ca}^{2+}$ permeable. Under voltage clamp, the increase in $\left[\mathrm{Ca}^{2+}\right]_{\mathrm{i}}$ during kainate application is most likely caused by a direct entry of $\mathrm{Ca}^{2+}$ through $\mathrm{Ca}^{2+}$-permeable kainate channels expressed by these neurons. It is unlikely to be caused by $\mathrm{Ca}^{2+}$ entry through voltage-gated $\mathrm{Ca}^{2+}$ channels because the cells were held at $-70 \mathrm{mV}$ and because the increase in $\left[\mathrm{Ca}^{2+}\right]_{\mathrm{i}}$ was also present in the $0 \mathrm{Na} / 10 \mathrm{Ca}$ bath, a condition under which minimal depolarization occurs. It is unlikely to be caused by a $\mathrm{Ca}^{2+}$ release from internal stores because the $I-V$ relationship was inwardly rectifying in neurons showing kainate-induced $\mathrm{Ca}^{2+}$ entry under voltage-clamp conditions. This inward rectification is a hallmark of $\mathrm{Ca}^{2+}$-permeable kainate receptors (Burnashev et al., 1995).

\section{Developmental change in $\mathrm{Ca}^{2+}$ permeability of kainate receptors}

Our study demonstrates that the rapid decrease in relative $\mathrm{Ca}^{2+}$ permeability of kainate receptors over late embryonic and early postnatal times correlates reasonably well with the time course of change in the extent of Q/R editing of GluR5 mRNA. The extent of editing increased from $23 \%$ at E16 to $79 \%$ at $\mathrm{P} 0$ and $>97 \%$ at P7. By our measure, $\mathrm{Ca}^{2+}$ permeability of kainate receptors became uniformly low by $\mathrm{P} 4$. Thus there is a close correspondence between the degree of editing and $\mathrm{Ca}^{2+}$ permeability. Yet, by analogy to the AMPA receptor in which the inclusion of one edited GluR2 is sufficient to cause low $\mathrm{Ca}^{2+}$ permeability of heteromeric AMPA receptors (Geiger et al., 1995; Washburn et al., 1997), the presence of one edited GluR5(R) might be sufficient to make kainate receptors $\mathrm{Ca}^{2+}$ impermeable. On the basis of this assumption, it is expected that essentially none of the kainate receptors would be $\mathrm{Ca}^{2+}$ permeable at $\mathrm{P} 0$ when nearly $80 \%$ of the mRNA is edited. Yet all DRG neurons tested at that age showed substantial $\mathrm{Ca}^{2+}$ permeability. This suggests that the properties of functional kainate receptors on the plasma membrane of DRG neurons may not directly reflect the mRNA present in the cell because of rate-limiting aspects of receptor protein synthesis and turnover. Alternatively, the subunit configuration of kainate receptors may influence their $\mathrm{Ca}^{2+}$ permeability with somewhat different rules than those of AMPA receptors.

GluR5 is the predominant kainate receptor subunit expressed by DRG neurons (Partin et al., 1993). By in situ hybridization, the
mRNA for GluR5 was shown to be specifically localized in small-diameter DRG neurons (Sato et al., 1993). Smaller amounts of other subunits were also detected including GluR6, GluR7, KA1, and KA2 (Partin et al., 1993). Results from our Q/Rediting experiments suggest that there is a developmentally regulated, dynamic change in the relative ratio of GluR5(Q) and GluR5(R) subunits. In addition, however, other kainate receptor subunits could contribute to a heteromeric receptor configuration with GluR5, modifying channel properties (Herb et al., 1992; Cui and Mayer, 1999).

\section{Identity of DRG neurons expressing functional kainate receptors}

Huettner (1990) was the first to report the presence of kainate receptors on a subpopulation of DRG neurons that he described as having intermediate and small diameters. Taken together with the observation that the agonist kainate depresses compound action potentials recorded from C-fibers (Agrawal and Evans, 1986), these data suggest that kainate receptors are expressed by nociceptors. Using a panel of markers for different subpopulations of nociceptors, we have tested which subpopulations of DRG neurons express functional kainate receptors and have found them to be expressed on substance P-negative, SSEA4negative, LA4 and IB4-positive, and LD2-positive DRG neurons. LA4 and IB4-positive neurons are C-fiber-type nociceptors as shown by Fang et al. (2000) who directly demonstrated that all IB4-labeled DRG neurons are C-fiber neurons.

Although LA4 alone accounts for $92 \%$ of the DRG neurons expressing kainate receptors, LA4 and LD2 together account for $100 \%$ of these neurons, indicating that LD2 must label a population of DRG neurons not labeled by LA4. The LA4-positive neurons represent a larger part of the total DRG population than do LD2-positive neurons in the ganglion from adult rats (50 vs $25 \%$ ) (Dodd and Jessell, 1985) and in our acutely dissociated preparation from newborn pups (72 vs 19\%; see Fig. 6). The LA4-positive neurons include nearly all of the FRAP-positive and all of the somatostatin (SOM)-positive afferents. The LD2positive neurons also include all of the SOM-positive afferents and a few of the FRAP-positive afferents (Dodd and Jessell, 1985). Thus it is likely that essentially all DRG neurons expressing functional kainate receptor are FRAP and SOM positive.

$\mathrm{C}$-fiber neurons expressing kainate receptors and projecting to lamina II are not expected to be sensitive to a uniform sensory modality. In a double-label experiment, 58\% of LA4-positive neurons were positive for VR1 (our unpublished observation). This distribution is comparable with the findings of Guo et al. (1999) who reported $67 \%$ of IB4-positive neurons showing an overlap with VR1 in intact ganglia. In our experiments, $60 \%$ of kainate-responsive cells were positive for antibody to VR1, and $71 \%$ of the kainate-sensitive neurons were sensitive to capsaicin, an agonist for VR1. Only these capsaicin-sensitive, VR1-positive neurons are likely to be nociceptors sensitive to noxious heat (Caterina et al., 2000), indicating that there is more than one sensory modality represented in this LA4-positive, kainate receptor-positive population of neurons.

\section{Possible role of $\mathrm{Ca}^{2+}$-permeable kainate receptors in developing sensory axons}

In a recent study, the physiological significance of $Q / R$ editing of GluR5 was tested by generating a mouse with genetically altered GluR5 so that all GluR5 mRNA was in the GluR5(R) form (Sailer et al., 1999). No developmental abnormalities were de- 
tected in these animals, nor did they show deficits in the behavioral tests conducted in the study, although there was a sixfold decrease in kainate current density in postnatal DRG neurons. However, the nociceptive testing in these experiments was limited, leaving open the possibility of a role for $\mathrm{Ca}^{2+}$-permeable kainate receptors in nociceptor development.

The timing of the switch of $\mathrm{Ca}^{2+}$ permeability and of the sharp increase in the extent of GluR5 Q/R editing coincides with important changes in the invasion of $\mathrm{C}$-fiber primary afferent axons in the spinal cord dorsal horn and their synaptic termination there. Although large-diameter dorsal root afferent collaterals begin to grow into the dorsal horn at E15 in the rat (Smith, 1983; Fitzgerald et al., 1991), C-fibers, including those expressing IB4, grow into the superficial dorsal horn from approximately E17 and later (Fitzgerald, 1987; Mirnics and Koerber, 1995; Jackman and Fitzgerald, 2000). Substance P- and FRAPcontaining fibers are clearly evident in laminas I and II by P1 (Fitzgerald and Gibson, 1984). Indeed, C-type afferent terminals are observed to make simple synaptic connections in lamina IIi by P0, and by P2 many express FRAP. Some of these mature into glomerular endings by approximately P5 (Pignatelli et al., 1989). Although the fibers are present in the dorsal horn, robust C-fiberevoked responses are not observed during the first postnatal week, whereas A-fiber-evoked responses are readily observed in neonates (Jennings and Fitzgerald, 1998). Because the kainate receptors are expressed by a subpopulation of sensory neurons projecting to lamina II of the dorsal horn and $\mathrm{Ca}^{2+}$ permeability of the receptors switches off at approximately the time of birth and over the first postnatal week, this change might be related to the $\mathrm{C}$-fiber invasion of spinal cord and the formation of early synaptic contacts between $\mathrm{C}$-fibers and target dorsal horn neurons.

In adult rat spinal cord, $\mathrm{A} \beta$ afferents are restricted to laminas III and IV, whereas in the neonate, the $\mathrm{A} \beta$ terminals extend dorsally into laminas I and II (Fitzgerald et al., 1994; Mirnics and Koerber, 1995). The A $\beta$ fibers then gradually withdraw from the superficial laminas over the first 3 postnatal weeks. C-fibers, on the other hand, grow specifically to laminas I and II before birth and for a considerable postnatal period; these laminas are occupied by both A- and C-fiber terminals (Fitzgerald et al., 1994). If $\mathrm{Ca}^{2+}$-permeable kainate receptors are expressed on the growth cones of growing $\mathrm{C}$-fiber axons, they might function as a signal for C-fibers to stop in lamina II and form synapses. One possible source of glutamate for triggering this stop signal could be from $\mathrm{A} \beta$ fiber terminals that are present in lamina II before birth. Later, kainate receptors would then switch to a $\mathrm{Ca}^{2+}$ impermeable form to serve yet another function, possibly as a modulator of synaptic release of glutamate from central terminals of primary afferents in the dorsal horn (Lee et al., 1999; Kerchner et al., 2001), as reported for mossy fibers in the hippocampus (Kamiya and Ozawa, 1999; Schmitz et al., 2000).

\section{REFERENCES}

Agrawal SG, Evans RH (1986) The primary afferent depolarizing action of kainate in the rat. Br J Pharmacol 87:345-355.

Bernard A, Khrestchatisky M (1994) Assessing the extent of RNA editing in the TMII regions of GluR5 and GluR6 kainate receptors during rat brain development. J Neurochem 62:2057-2060.

Bernard A, Ferhat L, Dessi F, Charton G, Represa A, Ben-Ari Y, Khrestchatisky M (1999) Q/R editing of the rat GluR5 and GluR6 kainate receptors in vivo and in vitro: evidence for independent developmental, pathological and cellular regulation. Eur J Neurosci 11:604-616.

Bettler B, Boulter J, Hermans-Borgmeyer I, O'Shea-Greenfield A, Deneris ES, Moll C, Borgmeyer U, Hollmann M, Heinemann S (1990)
Cloning of a novel glutamate receptor subunit, GluR5: expression in the nervous system during development. Neuron 5:583-595.

Burnashev N, Zhou Z, Neher E, Sakmann B (1995) Fractional calcium currents through recombinant GluR channels of the NMDA, AMPA and kainate receptor subtypes. J Physiol (Lond) 485:403-418.

Caterina MJ, Schumacher MA, Tominaga M, Rosen TA, Levine JD, Julius D (1997) The capsaicin receptor: a heat-activated ion channel in the pain pathway. Nature 389:816-824.

Caterina MJ, Leffler A, Malmberg AB, Martin WJ, Trafton J, PetersenZeitz KR, Koltzenburg M, Basbaum AI, Julius D (2000) Impaired nociception and pain sensation in mice lacking the capsaicin receptor. Science 288:306-313.

Chittajallu R, Braithwaite SP, Clarke VR, Henley JM (1999) Kainate receptors: subunits, synaptic localization and function. Trends Pharmacol Sci 20:26-35.

Cui C, Mayer ML (1999) Heteromeric kainate receptors formed by the coassembly of GluR5, GluR6, and GluR7. J Neurosci 19:8281-8291.

Dodd J, Jessell TM (1985) Lactoseries carbohydrates specify subsets of dorsal root ganglion neurons projecting to the superficial dorsal horn of rat spinal cord. J Neurosci 5:3278-3294.

Donevan SD, Beg A, Gunther JM, Twyman RE (1998) The methylglutamate, SYM 2081, is a potent and highly selective agonist at kainate receptors. J Pharmacol Exp Ther 285:539-545.

Fang X, Djouhri L, Lawson SN (2000) Sensory receptor properties of isolectin B4-positive (IB4+) and -negative (IB4-) dorsal root ganglion (DRG) neurones in vivo in the rat. Soc Neurosci Abstr 26:354.9.

Fitzgerald M (1987) Prenatal growth of fine-diameter primary afferents into the rat spinal cord: a transganglionic tracer study. J Comp Neurol 261:98-104.

Fitzgerald M, Gibson S (1984) The postnatal physiological and neurochemical development of peripheral sensory $\mathrm{C}$ fibres. Neuroscience 13:933-944.

Fitzgerald M, Reynolds ML, Benowitz LI (1991) GAP-43 expression in the developing rat lumbar spinal cord. Neuroscience 41:187-199.

Fitzgerald M, Butcher T, Shortland P (1994) Developmental changes in the laminar termination of A fibre cutaneous sensory afferents in the rat spinal cord dorsal horn. J Comp Neurol 348:225-233.

Geiger JR, Melcher T, Koh DS, Sakmann B, Seeburg PH, Jonas P, Monyer H (1995) Relative abundance of subunit mRNAs determines gating and $\mathrm{Ca}^{2+}$ permeability of AMPA receptors in principal neurons and interneurons in rat CNS. Neuron 15:193-204.

Gu JG, MacDermott AB (1997) Activation of ATP P2X receptors elicits glutamate release from sensory neuron synapses. Nature 389:749-753.

Gu JG, Albuquerque C, Lee CJ, MacDermott AB (1996) Synaptic strengthening through activation of $\mathrm{Ca}^{2+}$-permeable AMPA receptors. Nature 381:793-796.

Guo A, Vulchanova L, Wang J, Li X, Elde R (1999) Immunocytochemical localization of the vanilloid receptor 1 (VR1): relationship to neuropeptides, the P2X3 purinoceptor and IB4 binding sites. Eur J Neurosci 11:946-958.

Herb A, Burnashev N, Werner P, Sakmann B, Wisden W, Seeburg PH (1992) The KA-2 subunit of excitatory amino acid receptors shows widespread expression in brain and forms ion channels with distantly related subunits. Neuron 8:775-785.

Huettner JE (1990) Glutamate receptor channels in rat DRG neurons: activation by kainate and quisqualate and blockade of desensitization by Con A. Neuron 5:255-266.

Jackman A, Fitzgerald M (2000) Development of peripheral hindlimb and central spinal cord innervation by subpopulations of dorsal root ganglion cells in the embryonic rat. J Comp Neurol 418:281-298.

Jennings E, Fitzgerald M (1998) Postnatal changes in responses of rat dorsal horn cells to afferent stimulation: a fibre-induced sensitization. J Physiol (Lond) 509:859-868.

Kamiya H, Ozawa S (1999) Dual mechanism for presynaptic modulation by axonal metabotropic glutamate receptor at the mouse mossy fibre-CA3 synapse. J Physiol (Lond) 518:497-506.

Kerchner GA, Wilding TJ, Li P, Zhuo M, Huettner JE (2001) Presynaptic kainate receptors regulate spinal sensory transmission. J Neurosci 21:59-66.

Kyrozis A, Goldstein PA, Heath MJ, MacDermott AB (1995) Calcium entry through a subpopulation of AMPA receptors desensitized neighbouring NMDA receptors in rat dorsal horn neurons. J Physiol (Lond) 485:373-381.

Lee CJ, Engelman HS, MacDermott AB (1999) Activation of kainate receptors on rat sensory neurons evokes action potential firing and may modulate transmitter release. Ann NY Acad Sci 868:546-549.

Mirnics K, Koerber HR (1995) Prenatal development of rat primary afferent fibers. II. Central projections. J Comp Neurol 355:601-614.

Partin KM, Patneau DK, Winters CA, Mayer ML, Buonanno A (1993) Selective modulation of desensitization at AMPA versus kainate receptors by cyclothiazide and concanavalin A. Neuron 11:1069-1082.

Paschen W, Schmitt J, Dux E, Djuricic B (1995) Temporal analysis of the upregulation of GluR5 mRNA editing with age: regional evaluation. Brain Res Dev Brain Res 86:359-363.

Pemberton KE, Belcher SM, Ripellino JA, Howe JR (1998) High- 
affinity kainate-type ion channels in rat cerebellar granule cells. J Physiol (Lond) 510:401-420.

Pignatelli D, Ribeiro-da-Silva A, Coimbra A (1989) Postnatal maturation of primary afferent terminations in the substantia gelatinosa of the rat spinal cord. An electron microscopic study. Brain Res 491:33-44.

Ruano D, Lambolez B, Rossier J, Paternain AV, Lerma J (1995) Kainate receptor subunits expressed in single cultured hippocampal neurons: molecular and functional variants by RNA editing. Neuron 14:1009-1017.

Sailer A, Swanson GT, Perez-Otano I, O'Leary L, Malkmus SA, Dyck RH, Dickinson-Anson H, Schiffer HH, Maron C, Yaksh TL, Gage FH, O'Gorman S, Heinemann SF (1999) Generation and analysis of GluR5(Q636R) kainate receptor mutant mice. J Neurosci 19:8757-8764.

Sato K, Kiyama H, Park HT, Tohyama M (1993) AMPA, KA and NMDA receptors are expressed in the rat DRG neurones. NeuroReport 4:1263-1265

Schmitz D, Frerking M, Nicoll RA (2000) Synaptic activation of presynaptic kainate receptors on hippocampal mossy fiber synapses. Neuron 27:327-338.

Smith CL (1983) The development and postnatal organization of primary afferent projections to the rat thoracic spinal cord. J Comp Neurol 220:29-43.

Smith TC, Wang LY, Howe JR (1999) Distinct kainate receptor pheno- types in immature and mature mouse cerebellar granule cells. J Physiol (Lond) 517:51-58.

Sommer B, Kohler M, Sprengel R, Seeburg PH (1991) RNA editing in brain controls a determinant of ion flow in glutamate-gated channels. Cell 67:11-19.

Stucky CL, Lewin GR (1999) Isolectin B(4)-positive and -negative nociceptors are functionally distinct. J Neurosci 19:6497-6505.

Swanson GT, Feldmeyer D, Kaneda M, Cull-Candy SG (1996) Effect of RNA editing and subunit co-assembly single-channel properties of recombinant kainate receptors. J Physiol (Lond) 492:129-142.

Todd AJ, Spike RC (1993) The localization of classical transmitters and neuropeptides within neurons in laminae I-III of the mammalian spinal dorsal horn. Prog Neurobiol 41:609-645.

Tominaga M, Caterina MJ, Malmberg AB, Rosen TA, Gilbert H, Skinner K, Raumann BE, Basbaum AI, Julius D (1998) The cloned capsaicin receptor integrates multiple pain-producing stimuli. Neuron 21:531-543.

Washburn MS, Numberger M, Zhang S, Dingledine R (1997) Differential dependence on GluR2 expression of three characteristic features of AMPA receptors. J Neurosci 17:9393-9406.

Zhou LM, Gu ZQ, Costa AM, Yamada KA, Mansson PE, Giordano T, Skolnick P, Jones KA (1997) (2S,4R)-4-methylglutamic acid (SYM 2081): a selective, high-affinity ligand for kainate receptors. J Pharmacol Exp Ther 280:422-427. 